\title{
JAWABAN SOAL UTS 2018/2019 MATAKULIAH HAKI
}

\section{Niko saputra}

155100054

Fakultas Komputer,448757190

nikosaputra.student@umitra.ac.id

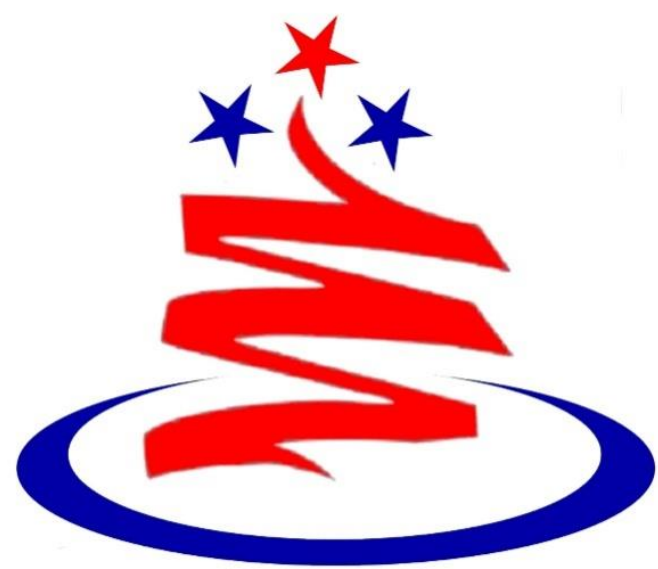

UnIVERSITAS mITRA InDONESIA 


\section{A. STUDI KASUS ( SK )}

Pertanyaan Type C :

paparkan dan jelaskan product knowledge KS?

Jawaban :

\section{HAK PATEN}

Huawei Technologies adalah perusahaan swasta berteknologi tinggi yang didirikan pada tahun 1988 oleh Ren Zhengfei yang mengkhususkan pada penelitian dan pengembangan (litbang), produksi dan pemasaran perangkat-perangkat telekomunikasi dan menyediakan solusi bagi operator penyelenggara telekomunikasi.

\section{MERK}

Huawei nova3i

\section{MERK DAGANG}

Huawei adalah salah satu Perusaahaan Information Communication Technology (ICT) dunia yang pada tahun 2014 berhasil masuk rangking 285 dari Fortune Global 500 Company.

"Huawei". Dalam bahasa Cina kata Huawei dituliskan dengan dua huruf, 华 dan 为.Huruf 华 berarti Cina dan 为 berarti sebuah prestasi atau action. Jadi, jika digabungkan nama Huawei berarti prestasi Cina. Nama yang pas untuk menggambarkan Huawei yang kini menjadi salah satu trendsetter smartphone dunia asal Cina.

\section{RAHASIA DAGANG}

31 Juli 2018 lalu Huawei resmi memperkenalkan flagship terba runya di Indonesia, yaitu seri ke-3 Huawei Nova yang diberi nama Nova 3i. Smartphone ini dilengkapi banyak teknologi cerdas (AI) pada berbagai fitur yang dimilikinya. Selain desainnya yang banyak dibilang fashionable dan enak dilihat

\section{DISAIN INDUSTRI}

$>$ WARNA

Hitam dan iris purple

$>$ LAYAR

Ukuran:

6,3 inch

Warna:

16,7 juta warna

Ukuran Saturasi Warna

(NTSC):

85\% (typical value)

Typle:

TFT LCD (IPS

Resolusi:

FHD+ 2340 x 1080, 409 PPI

$>\mathrm{CPU}$

HUAWEI Kirin 710

4 x Cortex A73 2,2

$\mathrm{GHz}+4$ x Cortex A53

$1,7 \mathrm{GHz}$

$>$ SISTEM OPERASI Android 8.1 


\begin{abstract}
MEMORI
INE-LX2:

4 GB RAM + 128 GB

ROMmicro SD card slot:

support up to $256 \mathrm{~GB}$

(tidak ada standar

konfigurasi)

*Karena keterbatasan

dalam kekuatan

pemrosesan CPU, memori yang digunakan oleh sistem operasi dan aplikasi prainstal, kapasitas yang sebenarnya tersedia untuk pengguna mungkin kurang dari kapasitas memori yang disebutkan. Kpasitas memori yang sebenarnya dapat berubah karena pembaruan aplikasi, operasi pengguna, dan faktor terkait lainnya.
\end{abstract}

\section{JARINGAN}

INE-LX2 (Dual SIM)

4G LTE TDD: B38 / B40 /

B41 (2.545 - $2.655 \mathrm{MHz})$

4G LTE FDD: B1 / B3 / B5

/ B7 / B8 / B28

3G WCDMA: B1 / B5 / B8

2G GSM: B2 / B3 / B5 / B8

Secondary SIM card:

4G LTE TDD: B38 / B40 /

B41 (2.545 - $2.655 \mathrm{MHz})$

4G LTE FDD: B1 / B3 / B5

/ B7 / B8 / B28

3G WCDMA: B1 / B5 / B8

2G GSM: B2 / B3 / B5 / B8

$>$ GPS

GPS, GLONASS, BeiDou

(hanya didukung oleh beberapa INE-LX2 yang dijual di Asia Pasifik), AGPS

\section{KONEKTIVITAS}

$802.11 \mathrm{~b} / \mathrm{g} / \mathrm{n}, 2.4 \mathrm{GHz}$

Bluetooth 4.2, BLE, HWA, aptX and aptX HD

Micro USB, USB 2.0

3,5 mm Headset Jack

PC

Data

Synchronization

\section{SENSOR}

Sensor Gravitasi

Sensor Cahaya

Sensor Sentuh

Giroskop

Kompas

Sensor Sidik Jari

$>$ KAMERA

Kamera Belakang:

16 mega-pixel (color) + 2 mega-pixel (color), F/2.2 aperture, supports autofocus (phase focus, contrast focus)

Kamera Depan: 24 mega-pixel (color) +2 mega-pixel(color), F/2.0 aperture, supports fixed focal length

*Piksel foto dapat bervariasi tergantung pada mode pemotretan. 


\section{B. STUDI REFERENSI ( SP )}

Pertanyaan Jenis B :

Jelaskan pasal pasal pendukung dalam hak atas kekayaan intelektual

Jawaban :

Sejalan dengan masuknya Indonesia sebagi anggota WTO/TRIP's dan diratifikasinya beberapa konvensi internasional di bidang HAKI sebagaimana dijelaskan pada pengaturan HAKI di internasional tersebut di atas, maka Indonesia harus menyelaraskan peraturan perundang-undangan di bidang HAKI. Untuk itu, pada tahun 1997 Pemerintah merevisi kembali beberapa peraturan perundangan di bidang HAKI, dengan mengundangkan:

Undang-undang No. 12 Tahun 1997 tentang Perubahan atas Undang-undang No. 6 Tahun 1982 sebagaimana telah diubah dengan Undang-undang No. 7 Tahun 1987 tentang Hak Cipta Undang-undang No. 13 Tahun 1997 tentang Perubahan atas Undang-undang No. 6 Tahun 1989 tentang Paten

Undang-undang No. 14 Tahun 1997 tentang Perubahan atas Undang-undang No. 19 Tahun 1992 tentang Merek

Selain ketiga undang-undang tersebut di atas, undang-undang HAKI yang menyangkut ke-7 HAKI antara lain:

1) Undang-undang No. 19 Tahun 2002 tentang Hak Cipta

2) Undang-undang No. 14 Tahun 2001 tentang Paten
3) Undang-undang No. 15 Tahun 2001 tentang Merk

4) Undang-undang No. 30 Tahun 2000 tentang Rahasia Dagang

5) Undang-undang No. 31 Tahun 2000 tentang Desain Industri

6) Undang-undang No. 32 Tahun 2000 tentang Desain Tata Letak Sirkuit Terpadu

7) Undang-undang No. 29 Tahun 2000 tentang Perlindungan Varietas Tanaman

Dengan pertimbangan masih perlu dilakukan penyempurnaan terhadap undang-undang tentang hak cipta, paten, dan merek yang diundangkan tahun 1997, maka ketiga undangundang tersebut telah direvisi kembali pada tahun 2001. Selanjutnya telah diundangkan:

Undang-undang No. 14 Tahun 2001 tentang Paten Undang-undang No. 15 Tahun 2001 tentang Merek (khusus mengenai revisi UU tentang Hak Cipta saat ini masih dalam proses pembahasan di DPR)

I. Lingkup Perlindungan HAKI HAKI memiliki ruang lingkup untuk mengetahui berbagai jenis hak intelektual yang dilindungi. Berikut ini merupakan lingkup perlindungan HAKI:

a. Hak Cipta (Copyright)

World Intellectual Property Organization (WIPO) pada tahun 2001 telah menetapkan tanggal 26 April sebagai Hari Hak Kekayaan Intelektual Sedunia:

b. Hak Milik Industri (Industrial Property)

c. Paten

d. Paten Sederhana

e. Merek \& Indikasi Geografis 
f. Desain Industri

g. Rahasia Dagang

h. Desain Tata Letak Sirkit Terpadu

i. Perlindungan Varietas Tanaman

Hak Cipta (copyright)

j. Melindungi sebuah karya

k. Hak khusus bagi pencipta maupun penerima hak untuk mengumumkan atau memperbanyak ciptaannya maupun memberi izin

untuk itu dengan tidak mengurangi pembatasan-pembatasan menurut

Peraturan Perundangundangan yang berlaku.

1.Orang lain berhak membuat karya lain yang fungsinya sama asalkan tidak dibuat berdasarkan karya orang lain yang memiliki hak cipta. Hak-hak tersebut adalah sebagai berikut:

hak-hak untuk membuat salinan dari ciptaannya tersebut,

hak untuk membuat produk derivative hak-hak untuk menyerahkan hak-hak tersebut ke pihak lain.

m.Hak cipta berlaku seketika setelah ciptaan tersebut dibuat.

n. Hak cipta tidak perlu didaftarkan terlebih dahulu.

Ciptaan yang dapat dilindungi oleh UU Hak Cipta, diantaranya sebagai berikut:

Buku, program komputer, pamflet, perwajahan (lay out) karya tulis yang diterbitkan dan semua hasil karya tulis lain.

Ceramah, kuliah, pidato dan ciptaan lain yang diwujudkan dengan cara diucapkan.

Alat peraga yang dibuat untuk kepentingan pendidikan dan ilmu pengetahuan.

Karya Seni, yaitu:

Seni rupa dengan segala bentuk seperti seni lukis, gambar, seni ukir, seni kaligrafi, seni pahat,seni patung, kolase dan seni terapan, seni batik, fotografi.

Ciptaan lagu atau musik dengan atau tanpa teks.

Drama, drama musikal, tari, koreografi, pewayangan, pantomim, sinematografi.

Arsitektur, Peta.

Terjemahan, tafsir, saduran, bunga rampai, database dan karya lain dari hasil pengalihwujudan.

Hukum Kekayaan Intelektual (HAKI) di bidang hak cipta memberikan sanksi jika terjadi pelanggaran terhadap tindak pidana di bidang hak cipta yaitu pidana penjara dan/atau denda, hal ini sesuai dengan ketentuan pidana dan/atau denda dalam UU No. 19 Tahun 2002 tentang Hak Cipta sebagai berikut:

Pasal 72 ayat (1) : Barangsiapa dengan sengaja dan tanpa hak melakukan perbuatan sebagaimana dimaksud dalam Pasal 2 ayat (1) atau Pasal 49 ayat (1) dan ayat (2) dipidana dengan pidana penjara masing-masing paling singkat 1 (satu) bulan dan/atau denda paling sedikit Rp. 1.000.000,- (satu juta rupiah), atau pidana penjara paling lama 7 (tujuh) tahun dan/atau denda paling banyak Rp. 5.000.000.000,(lima miliar rupiah).

Pasal 72 ayat (2) : Barangsiapa dengan sengaja menyiarkan, memamerkan, mengedarkan, atau menjual kepada umum suatu ciptaan atau barang hasil pelanggaran hak cipta atau hak terkait sebagaimana dimaksud pada ayat (1) dipidana dengan pidana penjara paling lama 5 (lima) tahun dan/atau denda paling banyak Rp. 500.000.000,- (lima ratus juta rupiah).

Pasal 72 ayat (3) : Barangsiapa dengan sengaja dan tanpa hak memperbanyak 
penggunaan untuk kepentingan komersial suatu program komputer, dipidana dengan pidana penjara paling lama 5 (lima) tahun dan/atau denda paling banyak Rp. 500.000.000,- (lima ratus juta rupiah).

Pasal 72 ayat (4) : Barangsiapa melanggar Pasal 17 dipidana dengan pidana penjara paling lama 5 (lima) tahun dan/atau denda paling banyak Rp. 1.000.000.000,- (satu miliar rupiah).

Pasal 72 ayat (5) : Barangsiapa dengan sengaja melanggar Pasal 19, Pasal 20, atau Pasal 49 ayat (3) dipidana dengan pidana penjara paling lama 2 (dua) tahun dan/atau denda paling banyak Rp. 150.000.000,- (seratus lima puluh juta rupiah).

Pasal 72 ayat (6) : Barangsiapa dengan sengaja dan tanpa hak melanggar Pasal 24 atau Pasal 55 dipidana dengan pidana penjara paling lama 2 (dua) tahun dan/atau denda paling banyak Rp. 150.000.000,- (seratus lima puluh juta rupiah).

Pasal 72 ayat (7) : Barangsiapa dengan sengaja dan tanpa hak melanggar Pasal 25 dipidana dengan pidana penjara paling lama 2 (dua) tahun dan/atau denda paling banyak Rp. 150.000.000,- (seratus lima puluh juta rupiah).

Pasal 72 ayat (8) : Barangsiapa dengan sengaja dan tanpa hak melanggar Pasal 27 dipidana dengan pidana penjara paling lama 2 (dua) tahun dan/atau denda paling banyak Rp. 150.000.000,- (seratus lima puluh juta rupiah).

Pasal 72 ayat (9) : Barangsiapa dengan sengaja melanggar Pasal 28 dipidana dengan pidana penjara paling lama 5 (lima) tahun dan/atau denda paling banyak Rp. 150.000.000,- (seratus lima puluh juta rupiah).

Pasal 73 ayat (1) : Ciptaan atau barang yang merupakan hasil tindak pidana hak cipta atau hak terkait serta alat-alat yang digunakan untuk melakukan tindak pidana tersebut dirampas oleh negara untuk dimusnahkan.

Pasal 73 ayat (2) : Ciptaan sebagaimana dimaksud pada ayat (1) di bidang seni dan bersifat unik, dapat dipertimbangkan untuk tidak dimusnahkan.

Jelasnya yang dimaksud dengan "bersifat unik" adalah bersifat lain daripada yang lain, tidak ada persamaan dengan yang lain, atau yang bersifat khusus. Ketentuan pidana tersebut di atas, menunjukkan kepada pemegang hak cipta atau pemegang hak terkait lainnya untuk memantau perkara pelanggaran hak cipta kepada Pengadilan Niaga dengan sanksi perdata berupa ganti kerugian dan tidak menutup hak negara untuk menuntut perkara tindak pidana hak cipta kepada Pengadilan Niaga dengan sanksi pidana penjara bagi yang melanggar hak cipta tersebut. Ketentuan-ketentuan pidana dalam UU No. 19 Tahun 2002 tentang Hak Cipta dimaksudkan untuk memberikan ancaman pidana denda yang paling berat, paling banyak, sebagai salah satu upaya menangkal pelanggaran hak cipta, serta untuk melindungi pemegang hak cipta. 
C. STUDI PENALARAN ( SP )

Pertanyaan Kategori 3 :

Buatlah penjelasan secara detail produk blackberry dan beberapa bagian haki yang ikut serta di dalam nya?

Jawaban :

BlackBerry adalah telepon seluler yang memiliki kemampuan layanan push email, telepon, sms, menjelajah internet, BlackBerry Messenger (BBM), dan berbagai kemampuan nirkabel lainnya. Penggunaan gawai canggih ini begitu fenomenal belakangan ini, sampai menjadi suatu kebutuhan untuk fashion. BlackBerry pertama kali diperkenalkan pada tahun 1999 oleh perusahaan Kanada, BlackBerry. Kemampuannya menyampaikan informasi melalui jaringan data nirkabel dari layanan perusahaan telepon genggam hingga mengejutkan dunia

\section{SEJARAH BLACKBERY}

BlackBerry pertama kali diperkenalkan di Indonesia pada pertengahan Desember 2004 oleh operator Indosat dan perusahaan Starhub. Perusahaan Starhub merupakan pengejewantahan dari RIM yang merupakan rekan utama BlackBerry. Pasar BlackBerry kemudian diramaikan oleh dua operator besar lainnya di tanah air yakni Excelcom dan Telkomsel.

Akibat tuntutan pemerintah Indonesia, BlackBerry akhirnya membuka kantor perwakilan di Indonesia pada November 2010

\section{PRODUK UNGGULAN BLACK BERRY}

Produk yang menjadi andalan utama dan membuat BlackBerry digemari di pasar adalah fitur surat-e cepat (push e-mail). Produk ini mendapat sebutan surat-e cepat karena seluruh surat elektronik baru, daftar kontak, dan informasi jadwal (calendar) “ditampilkan" langsung ke dalam BlackBerry secara otomatis.

Seperti yang telah disebutkan di atas mengenai keunggulan dari BlackBerry, yaitu push e-mail. Dengan push e-mail semua surat elektronik masuk dapat diteruskan langsung ke ponsel. E-mail juga sudah mengalami proses kompresi dan scan di server BlackBerry sehingga aman dari virus. Lampiran berkas berupa dokumen Microsoft Office dan PDF dapat dibuka dengan mudah. Sebuah surat elektronik berukuran 1 MB jika diterima melalui push e-mail dapat menjadi $10 \mathrm{~KB}$ dengan isi yang tetap.

Pengguna tidak perlu mengakses Internet terlebih dulu dan membuka satu persatu surat elektronik yang masuk, atau pemeriksaan surat elektronik baru. Hal ini dimungkinkan karena pengguna akan terhubung 
secara terus-menerus dengan dunia maya melalui jaringan telepon seluler yang tersedia. Alat penyimpanan juga memungkinkan para pengguna untuk mengakses data yang sampai ketika berada di luar layanan jangkauan nirkabel. Begitu pengguna terhubung lagi, BlackBerry Enterprise Server akan menyampaikan data terbaru yang masuk.

Kelebihan lainnya adalah kemampuan BlackBerry yang dapat menampung surat elektronik hingga puluhan ribu tanpa ada risiko hang, asalkan masih ada memori tersisa.

BlackBerry juga bisa digunakan untuk chatting. Mirip dengan Yahoo Messenger yang bernama BlackBerry Messenger (BBM) yang berjalan melalui jaringan BlackBerry dengan memasukan nomor identitas unik atau PIN dari setiap ponsel BlackBerry. Semua layanan BlackBerry ini dikenal sangat aman, baik surat-e, chatting, maupun browsing. Untuk browsing Internet, data-data dari situs web sudah dikompresi sehingga lebih cepat dibuka.

\section{SISTEM OPERASI}

RIM menyediakan sistem operasi multi-tugas (multi-tasking operating system - OS) bagi BlackBerry yang memungkinkan penggunaan secara intens dari sebuah alat. OS menyediakan dukungan bagi MIDP 1.0 dan WAP 1.2. Versi sebelumnya memungkinkan sinkronisasi nirkabel melalui e-mail dan kalender Microsoft Exchange Server, dan juga e-mail Lotus Domino. Sementara OS 4 yang terbaru merupakan pelengkap dari MIDP 2.0, dan memungkinkan aktivasi nirkabel lengkap dan sinkronisasi dengan e-mail, kalender, dan lain-lain. BlackBerry OS pada BB10 mendukung $98 \%$ aplikasi Android 


\section{REFERENSI}

[1]A. S. Putra And O. M. Febriani, "Knowledge Management Online Application In Pdam Lampung Province," In Prosiding International Conference On Information Technology And Business (Icitb), 2018, Pp. 181-187.

[2]A. S. Putra, O. M. Febriani, And B. Bachry, "Implementasi Genetic Fuzzy System Untuk Mengidentifikasi Hasil Curian Kendaraan Bermotor Di Polda Lampung," J. Sist. Inf. Dan Manaj. Basis Data, Vol. 1, No. 1, Pp. 21-30, 2018.

[3]O. M. Febriani And A. S. Putra, "Sistem Informasi Monitoring Inventori Barang Pada Balai Riset Standardisasi Industri Bandar Lampung," J. Inform., Vol. 13, No. 1, Pp. 90-98, 2014.

[4]Putra, Arie Setya. "2018 Artikel Struktur Data, Audit Dan Jaringan Komputer." (2018).

[5]Putra, A. S. (2018, July 17). Paperplain Fundamental Create Application With Borland Delphi 7.0 University Of Mitra Indonesia. Retrieved From Osf.Io/Pbrn9. 